\title{
Uji Aktivitas Antimalaria dari Spons Xestospongia sp. Asal Pulau Yapen secara In Vivo
}

\author{
Murtihapsari ${ }^{*}$, Mathelda K. Roreng ${ }^{2}$, Apriani Parubak', Alif Rahman' \\ I Jurusan Pendidikan Kimia, Fakultas Keguruan dan Ilmu Pendidikan, Universitas Papua \\ Jl. Gunung Salju, Amban Manokwari, Papua Barat, 98314, Indonesia \\ 2Jurusan Teknologi Hasil Pertanian, Fakultas Teknologi Pertanian, Universitas Papua \\ Jl. Gunung Salju, Amban Manokwari, Papua Barat, 98314, Indonesia \\ Email: murtihapsari.kadarusman@gmail.com
}

\begin{abstract}
In vivo antimalarial activity of marine sponge Xestospongia sp. collected from Yapen Island, Papua

It is generally admitted that marine sponge has rich of secondary metabolite as alkaloids, peptides and terpene. Those various compounds can be used for antimalarial drug. This study aims to evaluate the in vivo antimalarial activity and to characterize the effectiveness of dose (ED 50 ) of $n$ hexane extracted from Xestospongia sp. by using the Plasmodium berghei infected to mices. In the present study, we used Peter's four day suppressive test, where the mice infected with Plasmodium berghei intra peritoneal with a suspension containing infected red blood cell origin from donor mice with parasitemia. Results of present study exhibited that the sponge Xestospongia sp. contains secondary metabolite including tritepenoid/steroid, alkaloid and saponin. Furthermore, an in vivo test revealed the affectivity dose (ED 50 ) was $0.24 \mathrm{mg} / \mathrm{kg}$ of body weight. This finding is categorized a signifant decreasing level of parasitemia.
\end{abstract}

Keywords: Antimalarial, mice, Plasmodium berghei, Xestospongia sp.

\begin{abstract}
Abstrak
Secara umum, spons laut mempunyai kandungan metabolit sekunder seperti alkaloid, peptide dan terpena. Berbagai senyawa tersebut dapat dimanfaatkan sebagai obat antimalaria. Penelitian ini bertujuan untuk mengetahui kandungan kimia dan mengevaluasi aktivitas antimalarial secara in vivo untuk efektivitas dosis (ED50) ekstrak n-heksana dari spons Xestospongia sp. dengan menggunakan Plasmodium berghei yang diinfeksi ke tikus. Penelitian ini digunakan metode the 4day Supresive Test, dimana mencit yang diinfeksi Plasmodium berghei secara intra peritoneal dengan suspensi yang mengandung sel darah merah terinfeksi yang berasal dari mencit donor. Hasil penelitian ini menunjukkan adanya kandungan metabolit sekunder diantaranya tritepenoid/steroid, alkaloid dan saponin. Selanjutnya, uji in vivo diperoleh nilai ED 50 sebesar 0,24 $\mathrm{mg} / \mathrm{kg}$ BB dikelompokan sangat baik, yang dapat menurunkan tingkat parasitemia secara signifikan. Dengan demikian, spons laut asal pulau Yapen dapat dijadikan sebagai sumber metabolit potensial untuk obat antimalaria.
\end{abstract}

Kata Kunci: Antimalaria, mencit, Plasmodium berghei, Xestospongia sp.

\section{PENDAHULUAN}

Kasus malaria tertinggi didominasi oleh parasit Plasmodium falciparum yang mencapai 68\%, sedangkan kasus tertinggi kedua disebabkan oleh Plasmodium vivax yang umum menginfeksi penduduk Afrika. Indonesia masih tergolong ke dalam klasifikasi dengan jumlah $>300.000$ kasus per tahun dengan tingkat kematian 0,1-1 orang/1.000 kasus. Kasus kematian malaria di Indonesia yang disebabkan oleh Plasmodium falciparum 
mencapai $16 \%$ per tahun. Kondisi ini terlihat jauh lebih membaik jika dibandingkan dengan India dengan tingkat kematian $65 \%$. Dilaporkan pula bahwa, Indonesia dan sembilan negara lainnya dapat menurunkan kasus malaria sebesar 40\% hingga 2020 nanti (WHO, 2018). Kasus malaria dari jenis parasit $P$. falciparum telah banyak diteliti dan resisten terhadap obat antimalaria seperti 4-amino kuinolin (Wongsrichanalai et al., 2002), klorokuin dan primakuin (Wellems \& Plowe, 2001), kina dan pirimetamin (Happi et al., 2005). Perkembangan obat terbaru turunan artemisinin (artesunat) banyak digunakan untuk terapi malaria. Namun demikian, obat artemisinin telah dilaporkan mengalami resisten di Kamboja (Dondorp et al., 2009). Indonesia adalah negara endemik malaria khususnya $P$. falciparum dan $P$. vivax (Dini et al., 2020) dimana kasus malaria yang terdokumentasi pada 2018 sebanyak 18.000 kasus. Di daerah Papua dan papua Barat dengan tingkat prevalensi tertinggi di Indonesia sebesar 12\%, pemerintah menerapkan pendekatan hibrid untuk mengeliminasi malaria yaitu Terapi Kombinasi Artemisinin dan Penyemprotan insektisida (Ipa et al., 2020; Dini et al., 2020).

Oleh karena itu, untuk mengatasi masalah resistensi $P$. falciparum perlu adanya usaha dalam menemukan alternatif obat malaria baru dan dijadikan sebagai prioritas utama penelitian bahan alam. Salah satu potensi yang dapat dimanfaatkan sebagai produk alternatif bahan alami untuk obat antimalaria adalah jenis organisme spons laut yang mudah ditemukan di perairan laut tropis di perairan Indo-Pasifik (Kuo et al., 2019). Spons laut telah dijadikan biota target untuk obatobatan terbaru dari lautan (marine drugs), mengingat jenis biota sesil ini termasuk primitf yang telah hidup sejak 580 juta tahun lalu, koloninya ditemukan melimpah di perairan laut tropis, termasuk Indonesia. Ratusan Kajian telah membuktikan bahwa spons laut telah berkontribusi pada peningkatan paten obat dari lautan seperti anti tumor, anti virus, anti inflamatori, anti malaria dan beragam treatmen kesehatan manusia (Aguiar et al., 2021).

Spons merupakan salah satu biota laut yang memiliki potensi kandungan bioaktif dengan tingkat kereaktifan yang besar (Huang et al., 2016). Spons mempunyai kemampuan untuk mensintesis berbagai komponen senyawa bioaktif seperti alkaloid, peptida dan terpena (Muhtadi, 2018). Berdasarkan pemanfaatannya yang lebih luas, potensi spons laut (genus Xestospongia) dapat dikategorikan sebagai objek potensial untuk pengembangan obat dari lautan. Potensi dan kandungan spons banyak dimanfaatkan sebagai senyawa bioaktif untuk antikanker, antimikroba, antivirus, antitumor dan antimalaria (Sipkema et al., 2004).

Spons laut Xestospongia sp., sebagai alternatif bahan alami untuk aktivitas antimalaria terbukti mengandung senyawa aktif terhadap malaria yaitu protein kinase yang diyakini dapat menghambat $P$. falciparum (Laurent et al., 2006). Selain itu, Murtihapsari et al. (2010) melaporkan bahwa ekstrak alkohol spons Xestospongia sp. asal pulau Ansus dan Yapen Papua dapat menghambat pertumbuhan $P$. falciparum dengan IC50 galur W2 0,009 dan D6 0,003 $\mu \mathrm{g} / \mathrm{mL}$. Murtihapsari, et al., 2013 bahwa fraksi IV Xestospongia sp. dengan pelarut heksana: etil asetat (3:1) merupakan fraksi teraktif sebagai antimalaria dengan nilai $\mathrm{IC}_{50} \quad 7,13$ $\mu \mathrm{g} / \mathrm{mL}$.

Selain itu, jenis Spons yang sama Xestospongia sp., asal Kaimana Papua Barat dilaporkan memiliki aktivitas antimalaria secara in vitro dengan nilai $I C_{50}$ berkisar antara 38,15-1,08 x 10-6 $\mu \mathrm{M}$ (Murtihapsari, 2016; 2017; 2018; 2019; 2020). Tujuan penelitian ini untuk mengetahui kandungan metabolit sekunder dan menentukan nilai $\mathrm{ED}_{50}$ dari uji aktivitas antimalaria secara in vivo pada spons laut Xestospongia sp. dalam bidang farmakologi khususnya sebagai kandidat obat malaria.

\section{MATERI DAN METODE}

Materi yang digunakan terdiri atas spons Xestospongia sp. asal pulau Yapen, khususnya di pantai Ansus (GPS : 01052'08' S - 136012'31"' E), sedangkan materi pendukung diantaranya alkohol (teknis), heksana (teknis), $\mathrm{HCl} 5 \%$, reagen meyer, etanol, $\mathrm{H}_{2} \mathrm{SO}_{4}$, metanol (teknis), eter (teknis), perekasi Lieberman Bochard, aquadest, $\mathrm{FeCl}_{3}$, mencit ICR berkelamin jantan, pewarna Geimsa, mencit pendonor, 
larutan alsever. Alat yang digunakan pada penelitian ini berupa seperangkat alat gelas laboratorium, rotary evaporator (Vacuum Pneumatic), waterbath, timbangan analitik FSAR210, mikroskop Olympus, dan serangkaian alat pengujian antimalaria secara in vivo dilakukan di Laboratorium Farmakologi dan Fitokimia Universitas Airlangga. Preparasi sampel spons Xestospongia sp. didapatkan dengan cara menyelam pada kisaran kedalaman 10-15 meter. Selanjutnya, sampel spons tersebut direndam dan diawetkan dengan menggunakan etanol teknis (70\%).

Ekstraksi sampel pada penelitian ini menggunakan metode ekstraksi maserasi. Ekstraksi spons sebanyak $700 \mathrm{~g}$ dipotongpotong halus, kemudian dimaserasi selama $2 x$ 24 jam ke dalam $2000 \mathrm{~mL} n$-heksana. Proses ini dilakukan dengan 3 kali pengulangan dan diberikan perlakuan pengadukan setiap hari. Filtrat yang diperoleh disatukan lalu diuapkan menggunakan rotary evaporator sampai diperoleh ekstrak pekat $n$-heksana. Tahap berikutnya dilanjutkan dengan menggunakan waterbath. Ekstrak pekat n-heksana yang diperoleh kemudian dipindahkan ke dalam botol-botol kecil atau vial dan ditutup rapat (Hanani et al., 2005). Ekstrak yang dihasilkan dianalisis kandungan metabolit sekunder dan kemudian digunakan pada tahap pengujian antimalaria secara in vivo dalam menghambat pertumbuhan Plasmodium berghei.

\section{Uji Kandungan Kimia}

Identifikasi kandungan kimia dalam ekstrak n-heksana Xestospongia sp. dilakukan terhadap kandungan metabolit sekunder golongan: alkaloid, flavanoid, triterpenoid atau steroid, saponin serta tanin (Harborne, 1987).

\section{Pengujian Ekstrak Heksana terhadap Parasit} Malaria Secara In Vivo (Abdulelah dan Abidin, 2007)

Penelitian ini menggunakan 35 mencit dengan ICR jantan dengan berat variatif antara 28-32 $\mathrm{g}$ dan berusia 8 minggu. Mencit yang digunakan adalah mencit yang telah memenuhi standar dimana mencit diberikan makanan khusus (pellet) dan minuman air secara ad libitum. Penelitian ini menggunakan metode The 4-day Supresive Test yaitu dengan cara memberikan perlakuan mulai dari hari ke-0 sampai hari ke-3. Mencit dibagi ke dalam kelompok kontrol negatif, kelompok kontrol positif, kelompok perlakuan ekstrak 0,$1 ; 1 ; 10$; $100 \mathrm{mg} / \mathrm{kgBB}$. Hari penginfeksian disebut DO (hari ke nol). Setelah 2-4 jam penginfeksian diperoleh mencit yang positif, kemudian dilakukan pengobatan sekali dalam sehari. Pemberian obat dimulai dari hari ke-0 sampai hari ke-3. Pengamatan angka parasitemia dilakukan dengan membuat preparat apusan darah tebal dan tipis yang diambil dari vena ekor pada hari ke-4 setelah pemberian ekstrak (Peter dan Robinson, 1992).

Pembuatan preparat darah dilakukan dengan meneteskan 1 tetes darah ke atas gelas obyek, kemudian dibuat sediaan apusan tipis dan tebal, darah dibiarkan sampai kering pada suhu kamar. Persen parasitemia dihitung menggunakan persamaan, (WHO, 2008):

$$
\begin{aligned}
& \text { Persen Parasitemia (\%) } \\
& \quad=\left(\frac{\text { eritrosit terinfeksi }}{ \pm 1000 \text { eristrosit }}\right) \times 100 \%
\end{aligned}
$$

Rumus untuk menentukan penghambatan pertumbuhan parasit, (WHO, 2008):

$$
\begin{gathered}
\text { Persen penghambatan }(\%) \\
\left\{\left(\frac{\text { uji parasitemia }}{\text { kontrol parasitemia }}\right) \times 100 \%\right\}
\end{gathered}
$$

Data yang dihasilkan dari penelitian ini disajikan dalam bentuk tabel yang menunjukkan presentasi penghambatan pertumbuhan parasit malaria P. berghei. Hasil pengujian senyawa metabolit sekunder disajikan dalam bentuk tabel, dan nilai ED50 ditentukan dengan menggunakan analisis probit.

\section{HASIL DAN PEMBAHASAN}

Hasil ekstraksi dengan menggunakan metode maserasi dihasilkan ekstrak $n$-heksana kental dengan berat 14,85 $\mathrm{g}$ dan rendemen sebesar $0,07 \%$ dari spons Xestospongia sp. asal pantai Ansus. Keseluruhan sampel yang dimaserasi sebanyak $21,35 \mathrm{~kg}$ dengan volume pelarut yang digunakan $41 \mathrm{~L}$. Hal ini 
menunjukkan hanya sekitar $0,07 \%$ komponen yang terlarut dalam pelarut $n$-heksana.

Penelitian lain dilaporkan oleh Murtihapsari, et al., (2013), bahwa ekstrak nheksana spons Xestospongia sp. yang terdapat di kawasan pantai Barawaikap Servi memiliki rendemen sebesar 0,26\%. Nilai ini menunjukkan rendemen pada hasil ekstraksi spons Xestospongia sp. asal pantai Barawaikap lebih besar dibandingkan ekstrak spons Xestospongia sp. asal pantai Ansus dan Yapen Murtihapsari et al., (2010). Perbedaan yang terjadi dapat dikarenakan oleh faktor lingkungan, dimana diasumsikan bahwa pada kondisi lingkungan yang berbeda, spesies yang sama belum tentu memiliki kandungan metabolit sekunder yang sama (Marzuki, 2018).

Hasil ekstraksi metode maserasi pada penelitian ini juga dipengaruhi oleh jenis pelarut. Berdasarkan laporan penelitian yang dilakukan oleh Murtihapsari et al., (2010), ekstrak metanol spons Xestospongia sp. yang terdapat di kawasan Yapen memiliki rendemen sebesar $3,16 \%$, ini menunjukkan rendemen pada hasil ekstrak $n$-heksana spons Xestospongia sp. lebih kecil dibandingkan hasil ekstrak metanol pada kawasan yang sama. Daya melarutkan yang tinggi berhubungan dengan kepolaran pelarut dan kepolaran bahan yang diekstraksi. Jenis pelarut polar menghasilkan rendemen yang lebih besar dibandingkan pelarut non polar yang menghasilkan rendemen lebih kecil atau lebih sedikit (Harborne, 1987).

Hasil Uji kandungan metabolit sekunder atau uji fitokimia merupakan uji kualitatif yang dilakukan untuk mengetahui kandungan senyawa aktif dalam suatu bahan. Uji metabolit sekunder spons Xestospongia sp, dilakukan dengan mereaksikan ekstrak dengan suatu reagen tertentu (Harborne, 987). Hasil pengujian kandungan metabolit sekunder dapat dilihat pada Tabel 1.

Tabel 1, menunjukkan bahwa ekstrak $n$ heksana spons Xestospongia sp. mengandung alkaloid yang positif sedang. Hasil positif pada uji ditandai dengan terbentuknya endapan yang tidak begitu kuat. Menurut Harbone (1987), jika uji alkaloid hasilnya positif terjadi karena perubahan warna atau terbentuk endapan. Hasil penelitian ini, ekstrak yang diuji alkaloidnya membentuk endapan karena adanya pembentukan kompleks antara ion logam dari pereaksi yang digunakan dengan senyawa alkaloid. Uji triterpenoid atau steroid hasilnya positif sedang ditandai dengan terjadinya perubahan warna hijau yang tidak begitu pekat, perubahan warna yang tejadi yaitu warna kekuningan menjadi kehijauan. Menurut Robinson (1995), uji ini menandakan positif steroid bila terjadi perubahan warna merah kehijauan saat ekstrak ditambahkan pereaksi Liebarmen-Burchard.

Hasil uji saponin pada ekstrak $n$-heksana spons Xestospongia sp. hasilnya positif lemah ditandai dengan terbentuknya busa dengan jumlah yang sedikit dan stabil hingga 15 menit Menurut Robinson (1995), saponin adalah senyawa aktif permukaan yang dapat menimbulkan busa jika dikocok dalam air. Senyawa ini memiliki gugus polar dan nonpolar bersifat aktif permukaan sehingga saat dikocok dengan air, saponin dapat membentuk misel. Struktur misel terletak pada gugus polar menghadap ke luar sedangkan gugus nonpolarnya menghadap ke dalam, keadaan inilah yang tampak seperti busa (Robinson, 1995). Hasil uji tanin dan flavonoid diperoleh hasil negatif ditandai dengan tidak terjadi perubahan warna dan tidak terbentuk endapan untuk menandakan adanya tanin, sedangkan hasil negatif flavonoid ditandai

Tabel 1. Hasil pengujian kandungan metabolit sekunder Ekstrak $n$-heksana

\begin{tabular}{llcc}
\hline No & Komponen metabolit sekunder & Hasil & Perubahan \\
\hline 1 & Alkaloid & positif sedang & Terbentuk endapan \\
2 & Flavanoid & negatif & - \\
3 & Tritertenoid /Steroid & positif sedang & Kekuningan-kehijauan \\
4 & Tanin & negatif & - \\
5 & Saponin & positif lemah & Terbentuk busa \\
\hline
\end{tabular}


dengan tidak terjadinya perubahan warna menjadi merah untuk menandakan adanya senyawa metabolit sekunder flavonoid (Harborne, 1987).

Kandungan metabolit sekunder yang dimiliki oleh suatu mikroorganisme seperti spons yang terdapat pada lingkungan yang berbeda, sangat dipengaruhi kemampuan adaptasi, ketersediaan dan jejaring makanan serta interaksi intra sel spons itu sendiri (Marzuki, 2018). Kandungan senyawa spons laut juga dipengaruhi oleh kondisi subtrat dan mikroba asosiatifnya. Pertumbuhan spons laut banyak dipengaruhi oleh kondisi optimal dari proses up welling yang kaya nutrien selama musim selatan dan utara dan memanfaatkan arus bolak balik nutrien yang mengalir di bagian selatan samudera Hindia mulai dari perairan Asia timur laut hingga Melanesia (Hartoko 2007).

Hasil Pengujian ekstrak terhadap parasit malaria secara in vivo dengan menggunakan mencit ICR jantan berjumlah empat puluh dua ekor yang telah diinfeksi Plasmodium berghei. Plasmodium berghei merupakan parasit yang menyebabkan malaria pada golongan rodensia. Plasmodium jenis ini banyak digunakan dalam penelitian penyakit malaria (Isa et al., 2012). Data hasil pembacaan mikroskopik pengujian antimalaria dilihat pada Tabel 2.

Pemberian dosis $100,10,1,0,1 \mathrm{mg} / \mathrm{kgBB}$ memiliki pertumbuhan rata-rata persen parasitemia berturut-turut yaitu 6,09\%, 4,16\%, $3,13 \%$ dan $3,68 \%$. Hasil perhitungan tingkat parasitemia tertinggi pada dosis $100 \mathrm{mg} / \mathrm{kgBB}$ yaitu $\quad 6,09 \%$. Selanjutnya, persen penghambatan berturut-turut yaitu $7,87 \%$, $37,06 \%, 52,64 \%$ dan $44,33 \%$, dari data tersebut terlihat nilai persen penghambatan tertinggi pada $1 \mathrm{mg} / \mathrm{kgBB}$ yaitu sebesar $52,64 \%$, sedangkan nilai penghambatan terendah pada $100 \mathrm{mg} / \mathrm{kgBB}$ yaitu sebesar $7,87 \%$. Menurut Andrade-note et al., (2003) suatu ekstrak dikatakan aktif untuk menurunkan parasitemia apabila ekstrak tersebut dapat menurunkan parasitemia lebih dari $30 \%$. Jadi, dapat dikatakan pada pemberian dosis 10,1 , $0,1 \mathrm{mg} / \mathrm{kgBB}$ yang aktif untuk menurunkan tingkat parasitemia karena ketiganya memiliki persen penghambatan lebih dari $30 \%$.

Jika dibandingkan persen penghambatan spons Xestospongia sp. dengan penelitian dari beberapa filum invetebrata laut dari spesies Phallusia nigra dan Ascidia sydneiensis pada dosis $500 \mathrm{mg} / \mathrm{kg}$ dengan persen penghambatan masing-masing $61,00 \%$ dan 45,23\%. Spesies Holothuria sp. pada dosis 50 $\mathrm{mg} / \mathrm{kg}$ dengan persen penghambatan 25,97\%. Spesies Microscosmus goanus dan Echinaster echinophorus pada dosis 250 $\mathrm{mg} / \mathrm{kg}$ dengan persen penghambatan masing-masing 62,90 dan $17,31 \%$, sedangkan jika dilihat persen penghambatan spons Xestospongia sp. sangat tinggi untuk dosis 1 $\mathrm{mg} / \mathrm{kg}$ sebesar 52,64\% (Mendiola et al., 2006)

Penelitian ini digunakan kontrol positif data sekunder adalah klorokuin. Klorokuin merupakan turunan dari 4-aminokuinolin. Klorokuin memiliki efektivitas yang sangat tinggi terhadap $P$. vivax dan $P$. falciparum. Meski hanya efektif pada fase eritrosit, namun memiliki efek supresi yang lebih kuat dibanding dengan obat kina dan kuinakrin (Laksono, 2011). Hasil persen penghambatan yang telah diketahui kemudian dianalisis menggunakan analisis probit yang menyatakan nilai ED50 (efektivitas dosis 50\%) dengan membaca tabel probit. Harga $E_{50}$ menunjukkan besarnya dosis bahan uji yang dapat menghambat $50 \%$ pertumbuhan Plasmodium berghei. Jika semakin kecil harga ED50 maka semakin besar efektivitas

Tabel 2. Hasil Pengujian antimalaria ekstrak n-heksana spons Xestospongia sp.

\begin{tabular}{ccc}
\hline Dosis $(\mathrm{mg} / \mathrm{kgBB})$ & \% pertumbuhan & \%Penghambatan \\
\hline 100 & 6,09 & 7,87 \\
10 & 4,16 & 37,06 \\
1 & 3,13 & 52,64 \\
0,1 & 3,68 & 44,33 \\
$\mathrm{~K}$ & 6,61 & - \\
\hline
\end{tabular}


Tabel 3. Nilai $E D_{50}$ dari beberapa jenis spons dan kontrol positif

\begin{tabular}{llll}
\hline \multicolumn{1}{c}{ Sampel } & \multicolumn{1}{c}{$\begin{array}{c}\text { Pelarut/ } \\
\text { senyawa }\end{array}$} & $\begin{array}{c}\text { Nilai ED50 } \\
(\mathrm{mg} / \mathrm{kgBB})\end{array}$ & \multicolumn{1}{c}{ Sumber } \\
\hline Xestospongia sp. & n-heksana & 0,24 & Hasil Penelitian ini \\
Xestospongia sp. & Etanol & 331,95 & Syamsudin et al., 2013 \\
$\begin{array}{l}\text { Plakortis } \\
\text { Acanthostrongylophora }\end{array}$ & Quinolin & 6,10 & Campiani et al., 2007 \\
Kontrol Positif & Manzamin A & 55 & Hamann et al., 2007 \\
& Klorokuin & 0,67 & Data sekunder \\
& & & (Mustofa \& Sholikhah, 2007) \\
\hline
\end{tabular}

$\begin{array}{lrr}\text { penghambatan } & \text { ekstrak } & \text { terhadap } \\ \text { pertumbuhan } & \text { Plasmodium } & \text { berghei }\end{array}$ (Kusumawardhani et al., 2005).

Berdasarkan tabel probit terlihat harga ED50 pada penelitian ini terletak pada dosis $0,24 \mathrm{mg} / \mathrm{kgBB}$. Nilai ini dapat diartikan bahwa pemberian ekstrak $n$-heksana spons xestospongia $\mathrm{sp}$. pada dosis $0,24 \mathrm{mg} / \mathrm{kgBB}$ dapat menurunkan tingkat parasitemia $50 \%$. Jika dibandingkan dengan dengan nilai $\mathrm{ED}_{50}$ klorokuin, terlihat bahwa dosis ekstrak nheksana lebih kecil sehingga dapat dikatakan hasil penelitian ini sangat berpotensi. Menurut Isa et al., (2012), aktivitas antimalaria secara in vivo dikelompokkan menjadi sangat baik bila nilai $\mathrm{Ed}_{50}<100 \mathrm{mg} / \mathrm{kgBB} /$ hari, kategori baik bila nilai $\mathrm{ED}_{50}=101-250 \mathrm{mg} / \mathrm{kgBB} /$ hari. Kategori sedang bila nilai $E_{50}=251-500 \mathrm{mg} / \mathrm{kgBB} /$ hari dan tidak aktif jika $>500 \mathrm{mg} / \mathrm{kgBB} /$ hari. Menurut Syamsudin et al., (2013), ekstrak etanol dari spons Xestospongia sp. dapat menghambat pertumbuhan parasit $P$. berghei dengan dosis $331,95 \mathrm{mg} / \mathrm{kgBB}$. Quinolin yang diisolasi dari dari spons Genus Plakortis dapat menghambat pertumbuhan parasitemia dengan dosis $6,100 \mathrm{mg} / \mathrm{kgBB}$ (Campiani et al., 2007). Pada penelitian ini diperoleh nilai $\mathrm{ED}_{50}=$ $0,24 \mathrm{mg} / \mathrm{kgBB}$, dimana dapat dikelompokkan sangat baik untuk aktivitas antimalaria secara in vivo. Beberapa hasil ekstrak dan senyawa telah berhasil diperoleh dari spons yang berfungsi sebagai antimalaria. Perbandingan Nilai ED 50 dari hasil penelitian ini dan beberapa penelitian lainnya dapat dilihat pada Tabel 3.

\section{KESIMPULAN}

Spons Xestospongia sp. asal pulau Yapen mengandung metabolit sekunder diantaranya tritepenoid/steroid, alkaloid dan saponin. Selain itu, ekstrak $n$-heksana spons Xestospongia sp. pada dosis $0,24 \mathrm{mg} / \mathrm{kgBB}$ dapat menurunkan tingkat parasitemia secara signifikan.

\section{DAFTAR PUSTAKA}

Abdulelah, H.A.A \& Abidin, B.A.H. Z. 2007. Invivo Anti-Malarial Test of Nigella Sativa (Black Seed) Different Extracts. American Journal of Pharmacology and Toxicology, 2:46-50.

Aguiar, A.C.C., Parisi, J.R., Granito, R.N., de Sousa, L.R.F., Renno, A.C.M. \& Gazarini, M.L., 2021. Metabolites from Marine Sponges and Their Potential to Treat Malarial Protozoan Parasites Infection: A Systematic Review. Marine drugs, 19(3): p.134

Dini, S., Douglas, N.M., Poespoprodjo, J.R., Kenangalem, E., Sugiarto, P., Plumb, I.D., Price, R.N. \& Simpson, J.A., 2020. The risk of morbidity and mortality following recurrent malaria in Papua, Indonesia: a retrospective cohort study. BMC medicine, 18(1):1-12.

Dondorp, A.M., Nosten, F., Poravuth, Debashish, D., Phyo, A.P, Tarning, J., Khin, M.L, Ariey, F., Hanpithakpong, W., Lee, S.J., Ringwald, P., Silamut, K., Imwong, M., Chotivanich, K., Lim, P., Herdman, T., Sam An S., Shunmay, Y., Singhasivanon, P., Day, N.P.J., Lindegardh, N., Socheat, D., Nicholas, J. \& White, F.R.S. 2009. Artemisinin Resistance in Plasmodium falciparum Malaria. The New England Journal of Medicine, (361); 455-67.

Ebada, S.S. \& Proksch, P. 2012. The Chemistry of Marine Sponges. In Handbook of Marine Natural Products led. E. Fattorusso). Springer, London. 191.

Campiani, G., Gemma, S., Fattorusso, C., Kukreja, G., Joshi, B.P., Butini, S., Persico, M., Coccone, S.S. \& Bernetti, M., Giuseppe CAMPIANI, 2010. Novel 4-amino-quinoline 
derivatives useful as anti-malaria drugs. U.S. Patent Application 12/527,454.

Harborne. 1987. Metode Fitokimia Edisi Kedua. Patmawanata K, Soediro I, Penerjemah. Terjemahan dari : Phytochemical Methods. Bandung.ITB.

Hartoko, A. 2007. Vertical Temperature, The Fate of Up Welling and Spatial Distribution of Fish Biomass of North Papua Waters. Journal of Coastal Development. 10(3):181-187

Happi, C.T., Gbotosho, G.O., Folarin, O.A., Akinboye, D.O., Yusuf, B.O., Ebong, O.O. \& Odvola, A. M. J. 2005. Polymorphisms in Plasmodium falciparum genes and age related in vivo sulfadoxine-pyrimethamine resistance in malaria-infected patients from Nigeria. Acta tropica. 95(3);183-193.

Hanani, E., Mun'im, A., \& Sekarini, R., 2005. Identifikasi Senyawa Antioksidan dalam Spons dari Kepulauan Seribu, Majalah Ilmu Kefarmasian. 2(3):127-133. doi: 10.7454/psr.v2i3.3389.

Hamann, M.T., Hill, R., \& Roggod, S., 2007. Marine Natural Products. Key Advances to the Practical Application of this Resource in Drug Development. Natural products in drug discovery. 61:313-321. doi: 10.2533/ chimia.2007.313.

Huang, R.Y., Chen, W.T., Kurtan, T., Mandi, A., Ding, J., Li, J. \& Guo, Y.W. 2016. Bioactive isoquinolinequinone alkaloids from the South China Sea nudibranch Jorunna funebris and its sponge-prey Xestospongia sp. Future medicinal chemistry. 8(1):17-27.

Ipa, M., Widawati, M., Laksono, A.D., Kusrini, I. \& Dhewantara, P.W., 2020. Variation of preventive practices and its association with malaria infection in eastern Indonesia: Findings from communitybased survey. PloS one, 15(5):p.e0232909.

Isa, Rinadar \& Sugito. 2012. Aktivitas Antiplasmodium Daun Sernai (Wedelia Biflora) Berdasarkan Evaluasi Fungsi Ginjal dan Hati pada Mencit yang Diinfeksi dengan Plasmodium berghei. Jurnal veteriner. 13(2):167-175.

Kusumawardhani, D., Widyawaruyanti, A., \& Kusumawati. I., 2005. Efek Antimalaria Ekstrak Sambiloto Terstandar (Parameter Kadar Aandrografolida) Pada Mencit Terinfeksi Plasmodium Berghei. Majalah Farmasi Airlangga (Airlangga Journal of Pharmacy). 5(1): .25-29
Kuo, J., Yang, Y.T., Lu, M.C., Wong, T.Y., Sung, P.J., \& Huang, Y. S. 2019. Antimicrobial activity and diversity of bacteria associated with Taiwanese marine sponge Theonella swinhoei. Annals of Microbiology. 69(3):253-265.

Laksono, R.D. 2011. Profilaksis Malaria di Perbatasan Indonesia-Timor Leste. Jurnal Dokter Satgas YONIF 131 TNI AD. 38(7):503-507.

Laurent, D., Valerie J., Arnaud, P., Martine, K., Dominique, D., Sophie, S., Oliver, L., Nicolas, L., Maryvonne, F., Frederic, A., Severine, M., Christian, D., Laurent, M. \& Michel, S. 2006. Antimalarial Potential of Xestoquinone, a Protein Kinase Inhibitor from A Vanuatu Marine Sponge Xestospongia sp. Elsevier. Bioorganic \& Medicinal Chemistry. 4477-4482. doi : 10.1016/j.bmc.2006.02.026.

Marzuki, I. 2018. Eksplorasi Spons Indonesia: Seputar Kepulauan Spermonde. Penerbit Nas Media Pustaka. Cetakan pertama. Makassar. 158-159

Mendiola, J., Hernandez H., Idalia Sariego, I., Rojas, L., Otero A., Angel Ramirez, A., Chavez, Maria de los Angeles, Payrol, J,A., \& Aida, H. 2006. Antimalarial activity from three ascidians: an exploration of different marine invertebrate phyla. Tropical Medicine and Hygiene. 100:909-916.

Murtihapsari, Chasanah, E, \& Purwantiningsih. 2010. A New Candidate active compound from Papuan marine sponge. Poster Presentation. International Conference of Bioactive Compound. Bandung

Murtihapsari, Parubak, A.S., Mangallo, B., Ekasari, W., Asih, P.B., \& Lestari, A.Y. 2013. Isolation and Presence of Antimalarial Activities of Marine Sponge Xestospongia $\mathrm{sp}$. Indonesian Journal of Chemistry, 13(3):199- 204.

Murtihapsari, Kurnia, D, Herlina, T, \& Supratman, U, 2016. Senyawa steroid dari spons (Xestospongia sp.) dan aktivitasnya terhadap Plasmodium falciparum secara in vitro, Seminar Nasional Kimia UNJANI HKI 2016 3-4 Agustus 2016, Hotel Grand Tjokro, Bandung.

Murtihapsari, Jonathan, J.M, Kurnia D, Herlina $\mathrm{T}$, \& Supratman U, 2017. Antimalarial Compound from Papuan Marine Sponge Xestospongia sp. 2nd Internasional 
Seminar and Expo on Jamu, Ghra Sanusi Hardjadinata - UNPAD. 26-27 September 2017, Bandung

Murtihapsari, Suruwaky, A.M., Kadarusman, Kurnia, D., Herlina, T., \& Supratman, U. 2018. A New Antiplasmodial Compound from the Papuan Marine Sponge Xestospongia sp. Jurnal Kimia Valensi, $4(1): 1-6$.

Murtihapsari, Salam, S., Kurnia, D., Herlina, T., Darwati, Kadarusman, Abdullah, F.F., Husna, M.H., Awang, K., Yoshihito Shiono, Y., \& Supratman, U. 2019. Antiplasmodial Sterols from Indonesian Marine Sponge, Xestospongia sp. Natural Product Research. 1478-6427. doi: 10.1080/14786419.2019.1611815.

Murtihapsari, Kurnia, D., Herlina, T., Katja, D.G., Kadarusman, Awang, K., Shiono, Y., \& Supratman, U., 2020. Antiplasmodial Compounds from Indonesian Marine Sponge, Xestospongia sp, Against Plasmodium falciparum 3D7. CMU J. Nat. Sci. 19(3):487-497. doi: 10.12982/CMUJNS.2020.0032

Mustofa \& Sholikhah, E.N. 2007. Aktivitas antiplasmodium in vitro dan in vivo fraksi yang diperoleh dari ekstrak methanol pasak bumi (Eurycoma longifolia Jack) yang secara tradisional digunakan mengobati malaria di Kalimantan Selatan. Majalah Obat Tradisional., 11:2530.

Peter, W. \& Robinson, B.L. 1992. The Chemotheraphy of Rodent Malaria XLVII: Studies Pyronaridine and Other Mannich
Base Antimalarias Ann. Trop. Med. Parasitol. 86:455-465. doi: 10.1080/000349 83.1992.11812694.

Robinson, T. 1995. Kandungan Senyawa Organik Tumbuhan Tinggi. Diterjemahkan oleh Prof. Dr. Kosasih Padmawinata. Bandung : ITB.

Sipkema, D., Snijders, A.P.L, Schroen, C.G.P.H, Osinga, R, \& Wijffels, R. 2004. The life and death of sponge cells. Biotechnology and Bioengineering. 85(3):239-247.

Syamsudin, A., Rahmatul, W.A., Yatnita, P.C., \& Noriah, M.N. 2013. Evaluation of Antimalaria Activitiy and Acute Toxicity of Xestospongia sp. American Journal of Pharmacology and Toxicology. 799-803. doi : 10.1016/j.jopr.2013.08.001.

Wellems, T.E. \& Plowe, C.V. 2001. Chloroquineresistant malaria. Journal of Infectious Diseases. 184(6): 770-776.

Wongsrichanalai, C., Pickard, A. L., Wernsdorfer, W. H., \& Meshnick, S. R. 2002. Epidemiology of drug-resistant malaria. The Lancet infectious diseases. 2(4): 209218.

WHO (World Health Organization). 2008. In Vitro Micro-test (Mark III) For The Assessment of The Response of Plasmodium falciparum to Chloroquin, Mefloquine, Quinine, Amodiaquine, Sulfadoxine/Pyrimethamine and Artemisinin. Division of Control of Tropical Diseases. 1-30.

WHO (World Health Organization). 2018. World Malaria report 2018. 1-8 